\section{The Oxford Companion to New Zealand Literature}

\section{Edited by Roger Robinson and Nelson Wattie, Oxford University Press, Auckland \& Melbourne, 1998, 608 pp, $\$ 79.95$}

$\mathrm{T}$ HE LATEST in the extensive and highly-regarded series of Oxford Companions, this longawaited volume plugs one more gap in the still sparse shelf of New Zealand reference books. Various monumental images come to mind, and this particular milestone, or brick in the wall of our cultural identity, bears a great deal of weight. Though coruscating slightly less than it once did, the Oxford University Press imprint still confers its seal of authority. The Companion is one of a long-standing series of monuments to national literatures which by their inclusions and exclusions influence the way literary careers are assessed, reading habits and tastes formed and reputations defined.

The Oxford Companion to English Literature by Sir Paul Harvey (not Hervey, as on p.423 of the present work) was published in 1932 as OUP's answer to the successful Brewer's Dictionary of Phrase and
Fable. To the compiler's dismay the publisher insisted on the inclusion of entries for literary terms, periodi- cals and social clubs beside his pithy, stylish and often idiosyncratic entries for authors, plots, characters, a little classical background and recondite literary allusions. A grand success, it went through four editions before Margaret Drabble's comprehensive revision in 1985. Her labours took

five years, to produce a work of over 7000 unsigned entries by about seventy contributors. Drabble wanted her book 'to quickly, clearly and easily satisfy the immediate curiosity of the common reader' and provide direction to further sources of information. ${ }^{1}$ Authorship was not narrowly defined, and works were described and characterised, rather than judged. The family of literary Oxford Companions now encompasses over twenty volumes, a number in several editions (Australia and Canada two each, America six) and Oxford University Press seems currently almost profligate in its commissioning of new Companions in other fields, so there is no reason to assume the New Zealand child will be the last.

So the 'common reader' opens an Oxford Companion with certain expectations, among them balance, lucidity, concision and reliability. A survey and guide, it

will include an entry for any major author the reader can think of, at least in the 'serious' genres of drama, fiction and poetry; separate entries for the more important books; topical entries on matters relating to literature (perhaps publishing, criticism, common themes). Most of these expectations 
will be met by the present Companion, which contains more than 1500 signed entries by some ninety-four contributors (including nearly a third - over 450 by my count written wholly or in part by the two editors): 680 entries for authors and 110 titles. It has been in preparation for at least as long as Drabble's but the bulk of the concentrated work was done between 1994 and 1997 and works appearing since 1996 have only been briefly noted. The 'canon' of New Zealand literature (if there is such a thing) is generously treated:

Mansfield, Curnow, Frame, Sargeson, Baxter, et al. are all dealt with at length and in detail (there is almost a mini-Companion on Mansfield here). Others better qualified than this reviewer will evaluate the Companion's assessments of its subject matter. Many works are granted an extended essay, and there are substantial numbers of entries for Māori writing, for children's literature, music and film. There is also a useful appendix of New Zealand Literary Awards.

What this Companion most importantly provides, however, is a bringing together of a wealth of information which readers have hitherto had to hunt for in various sources of greater or lesser reliability - in individual biographies and critical studies, in A.H. McLintock's 1966 Encyclopaedia of New Zealand, in the individual volumes of the Dictionary of New Zealand Biography, in the genre surveys of the Oxford History of New Zealand Literature in English or the wider contexts of books like the Oxford History of New Zealand., and adding to it much new research. $^{2}$

It has been long awaited, and, whether we post-colonials like it or not, its existence bestows something of a stamp of approval on a literature we already know is distinctive, coverage of genres, overviews and bibliography. ${ }^{3}$ Despite this liberality, firm rules have been formulated to guide the compilers in their selection: writers who had not published two books before the end of 1996 are not generally included. Undoubtedly many battles have already been fought over these lines in the shifting sands of 'literature'.

Over the work falls the long shadow of the pioneer literary bushman, Eric McCormick, riding roughshod, a copy of Scrutiny in his saddlebag, through G.B. Lancaster's romances, Mrs Glenny Wilson's pastoral epics, or the 'lurid' Jean Devanny, to deliver through gritted teeth his reproach or approbation. ${ }^{4}$ It is not so easy these days to make categorical judgements. The compilers of a modern companion must be catholic in their tastes and inclusive in their criteria of what makes 'literature'. There
Whitcombe \& Tombs, Christchurch in 1919. Photo: Steffano Francis Webb. G-4275-1/1-, Alexander Turnbull Library. will certainly be real

discoveries in this volume for the common reader, especially, I think, in the hidden 'popular' genres of the last 150 years, an area in which Terry Sturm and Nelson Wattie have foraged to present much new detail here.

In their preface the editors defend themselves beforehand against many of the critical charges they will no doubt face. Given the factious and fractious nature of the New Zealand literary world (the lack of an entry for 'Literary feuds 
and controversies' is surely an opportunity missed!), it is unquestionable that the present volume has already given rise to much dinnertable argument, solitary fuming, and general raising of literary blood-pressure. Both delight and indignation will be experienced poring over the pages. Despite protestations that space indicates relative importance in only a general way, and that their choices in less 'literary' areas are bound to be debatable, it is tempting to measure in column inches some of the editors' predilections.

One suspects that they have given some of their hobby-horses a rather free rein. Non-fiction writers are erratically represented Michael King and Jamie Belich are here, but not Tony Simpson or Jock Phillips - while the early European voyagers seem to have been indulgently regarded, and some aberrant entries do stand out: Karl Wolfskehl, marginal in the New Zealand context, is adequately covered in the topic essay on 'Germany' and yet receives another four columns of his own; Samuel Butler, here for four years, receives three entries. While it is always a difficult task to balance the contents of such a large-scale production, especially against a publication deadline, tighter editorial control might have provided a more balanced result. In the absence of genre entries with cross-references, an index would also be a help in uncovering references to the many writers and titles which do not have an entry of their own.

The predominance of Victoria University contributions is hardly surprising and does not necessarily signal a pro-Wellington bias (in fact some gentle needling of the 'Manhire school' suggests the opposite, if anything). Major and important contributions are made by many writers from other locations. Although book titles are given entries only in the case of a relatively small number of major writers, no periodical is too obscure, it seems, to disqualify it if it once published something of a 'literary' nature. The 123 mostly short notes may look incongruous amongst a majority of articles which are a good deal more leisurely, but in the absence of genre surveys or a comprehensive index this is inevitable. New Zealand composers are similarly generously treated, and there does not seem to be one who was not sufficiently prescient to set a New Zealand stanza and thereby gain entry, though the editors in their preface assure us that there are even more who could not be included. Popular music is oddly treated: Neil Finn takes a token place, while his colleagues remain in the outer darkness. Some excluded may consider themselves fortunate to have escaped the subtle barbs of Roger Robinson's pen.

Perhaps surprising to find so extensively treated in a literary companion, although useful to the 'foreign' reader, are the many expository entries for New Zealand words and sayings, expanded by Harry Orsman from his recent Oxford Dictionary of New Zealand English. ${ }^{5}$ The editors have also gone to some trouble to ensure that Māori writing and writers take their place alongside English and 'rules' about numbers of publications have been set aside. Entries for Māori writers number over 50 of an overall 125 on Māori subjects, texts and topics. Unfortunately some of these show less sensitivity to Māoritanga than their inclusion intends to demonstrate. For instance, the categorical assertion that 'the leader of the hap $\bar{u}$ is the rangatira' (p.227) seems naive in late 1990s New Zealand.

As G.H. Scholefield noted on a sheet inserted in his 1940 Dictionary of New Zealand Biography, 'whatever care be expended on the production of a book, error of some sort is almost bound to creep in'. Second editions are always necessary, or one hopes for a reprint to enable minor defects to be repaired silently. But it is dismaying that small errors and inconsistencies abound in a work which aims to serve a reference as well as a browsing function. Reed's Arnold Wall was the son of the man to whose entry his name is crossreferenced (p.5); Elsie Locke's book is The Runaway Settlers, not Settler (p.58; correct on p.309); Robert Creeley's wife is Penelope Highton, not Highet (p.118); Rachel

Barrowman's A Popular Vision was published in 1991, not 1994 (pp.305, 452 and 453); Maurice Gee's Plumb was published by Oxford in tandem with Faber (pp.603 and 604) ... Even allowing for the pressures of publishers' schedules, it is a pity that a lack of rigour in the checking of details mars such a handsome and useful volume.

Most readers will agree that the editors' aim to inform and to please has certainly been achieved. On the 
balance of their coverage the jury will be out for some time, and the editors gave themselves such a broad brief that any case is likely to be thrown out of court; many entries are models of a lucid style, sometimes witty and waspish to boot; however conciseness is not

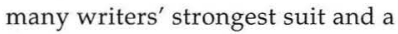
sharper wielding of the editorial scalpel might have made room for a broader representation of nonfiction; reliability is only compromised by minor flaws. Our first

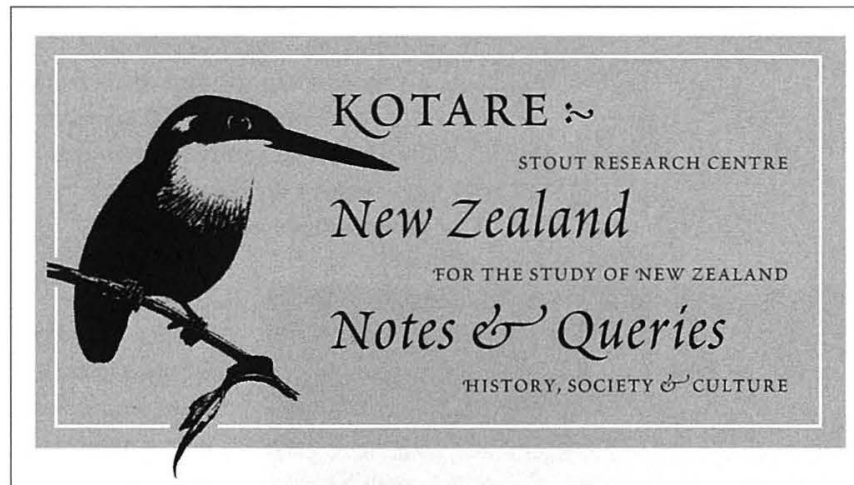

KOTARE: NEW ZEALAND NOTES AND QUERIES is a new bi-annual journal devoted to New Zealand studies, published by the Stout Research Centre. It is available on annual subscription - Individual sub: \$18 local, \$25 overseas; Institution sub: \$25 local; \$35 overseas.

Modelled on Oxford University Press's long-running Notes and Queries, Kotare provides an avenue for brief scholarly articles on a range of New Zealand subjects - history, literature, bibliography, lexicography, language and culture - and encourages the publication of manuscript material buried in archives around the country. Like its English counterpart, the journal will also include reviews of scholarly books (though not of fiction or poetry), and a forum for readers' queries (and replies to them!) and for scholars to let others know of work in progress.

Volume One: Number One, October 1998, includes articles by Stephen Hamilton, Giselle Byrnes, Lawrence Jones, Graeme Kennedy, Janet Holmes, Desmond Hurley, Rowan Gibbs and Dominic Alessio.

Contributions for further issues are invited - please contact the editor for submission requirements. Potential reviewers - please send short CVs to indicate your interest.

FOR ALL ENQUIRIES PLEASE CONTACT:

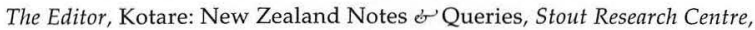
Victoria University of Wellington, PO Box 600, Wellington, fax 0-4-496 5439, e-mail:Peter.Whiteford@vuw.ac.nz or Paul.Millar@vuw.ac.nz

Oxford Companion to New Zealand Literature is to be applauded and welcomed. It will be turned to often as a ready-reference and a source of factual information and critical enlightenment, a boon to librarians, historians, students of literature and the 'common reader'. One hopes too that the editors' confidence that there will be further editions is not misplaced. $\infty$

\section{ROSS SOMERVILLE is a former} reference librarian and bibliographer, and an inveterate browser of reference books. Now an Assistant Editor at the Dictionary of New Zealand Biography in Wellington and Acting Production Manager for the Heritage Group of the Department of Internal Affairs, he is also a member of the Steering Committee of the Humanities Society of New Zealand's History of Print Culture in New Zealand project.

\section{Notes}

1 Drabble, Margaret, The Oxford Companion to English Literature, 5th ed., Oxford, Oxford University Press, 1985, p.v.

2 McLintock, A.H., ed., An Encyclopaedia of New Zealand, Wellington, Government Printer, 1966 (3 vols); Scholefield, G.H., A Dictionary of National Biography,

Wellington, Dept of Internal Affairs, 1940 (2 vols) or The Dictionary of New Zealand Biography, General Editor W.H. Oliver (Vol. 1), Claudia Orange (Vols 2-4), Wellington [etc.], Allen \& Unwin [etc.], Dept of Internal Affairs, 1990-98; Sturm, T, ed., The Oxford History of New Zealand Literature in English, Auckland, OUP, 1991, 2nd ed. 1998; The Oxford History of New Zealand, ed. W.H. Oliver with B.R. Williams, Oxford \& Auckland, Clarendon Press/OUP, 1981; 2nd ed., ed. Geoffrey W. Rice, Auckland, OUP, 1992.

3 Preface, pp.v-vi.

4 E.H. McCormick, Letters and Art in New Zealand, Wellington, Dept of Internal Affairs, 1940, p.148.

5 Orsman, H.W., The Dictionary of New Zealand English, Auckland, OUP, 1997. 